\title{
Air Pollution Levels Related to Peak Expiratory Flow Rates among Adult Asthmatics in Lampang, Thailand
}

\author{
Wanwisa Chujit ${ }^{1}$, Phongtape Wiwatanadate ${ }^{1^{*}}$, Athavudh Deesomchok ${ }^{2}$, Khajornsak Sopajaree ${ }^{3}$, \\ Kamal Eldeirawi ${ }^{4}$, Ying I. Tsai ${ }^{3,5,6^{* *}}$
}

\author{
${ }^{1}$ Department of Community Medicine, Faculty of Medicine, Chiang Mai University, Chiang Mai 50200, Thailand \\ ${ }^{2}$ Division of Pulmonary, Critical Care Medicine and Allergy, Department of Medicine, Faculty of Medicine, Chiang Mai \\ University, Chiang Mai 50200, Thailand \\ ${ }^{3}$ Department of Environmental Engineering, Chiang Mai University, Chiang Mai 50200, Thailand \\ ${ }^{4}$ Department of Health Systems Science, College of Nursing, University of Illinois at Chicago, Chicago, IL 60612, USA \\ ${ }^{5}$ Department of Environmental Engineering and Science, Chia Nan University of Pharmacy and Science, Tainan 71710 , \\ Taiwan \\ ${ }^{6}$ Indoor Air Quality Research and Service Center, Chia Nan University of Pharmacy and Science, Tainan 71710, Taiwan
}

\begin{abstract}
Asthmatics may suffer harmful health effects from air pollution. This year-long study, which was conducted from November 2015 till October 2016 and resulted in 12,045 data points from 33 participants, assessed the relationships (with a $95 \%$ confidence interval [CI]) between measured air pollutant $\left(\mathrm{CO}, \mathrm{NO}_{2}, \mathrm{O}_{3}, \mathrm{SO}_{2}, \mathrm{PM}_{2.5}\right.$ and $\left.\mathrm{PM}_{10}\right)$ concentrations and peak expiratory flow rates (PEFRs) among adults with asthma in the district of Mae Moh in Lampang, Thailand. A positive correlation was found between the mean daily concentration of $\mathrm{NO}_{2}$ from 4 days prior ("lag 4") and the PEFR upon waking ("morning PEFR"), with an increase of $1 \mathrm{ppb}$ in the former being associated with an increase of $1.34 \mathrm{~L} \mathrm{~min}{ }^{-1}$ (95\% CI: 0.25 , 2.44 ) in the latter. Also, the interaction between $\mathrm{NO}_{2}(\operatorname{lag} 4)$ and $\mathrm{PM}_{10}$ (lag 6) was multiplicatively associated with a decrease of $-0.015 \mathrm{~L} \mathrm{~min}^{-1}$ in the morning PEFR, which was also negatively associated with the maximum daily concentration ("max") of $\mathrm{NO}_{2}$ (lag 2) and that of $\mathrm{PM}_{10}$ (lag 6), with coefficients of -0.07 and -0.013 , respectively. Furthermore, when including $\mathrm{PM}_{2.5}$ max in the generalized estimating equation model, only $\mathrm{NO}_{2} \max (\operatorname{lag} 2)$ and $\mathrm{CO} \max ($ lag 6) were negatively associated with the morning PEFR, displaying coefficients of -0.08 and -1.71 , respectively. $\mathrm{O}_{3} \max (\operatorname{lag} 3)$ and $\mathrm{PM}_{2.5}$ max exhibited positive relationships with the PEFR before sleeping ("evening PEFR"), with coefficients of 0.078 and 0.029 , respectively. Additionally, the average daily PEFR was positively associated with the average daily concentration of $\mathrm{NO}_{2}$ (lag 4), with a coefficient of 0.15 , but negatively associated with that of $\mathrm{SO}_{2}$, with a coefficient of -0.47 . We also observed a negative relationship between the average daily PEFR and $\mathrm{NO}_{2} \max (\mathrm{lag} 2$ ), with a coefficient of -0.05 , but a positive one between the former and $\mathrm{O}_{3} \max (\operatorname{lag} 3$ ), with a coefficient of 0.06 . Our results indicate that the delayed-and, in some cases, negative - effects of these pollutants on PEFRs must be considered in health forecasting and that preventative measures should be implemented to control certain emissions at the source.
\end{abstract}

Keywords: Air pollution; Peak expiratory flow rates; Asthmatic patients; Mae Moh.

\section{INTRODUCTION}

Air pollution causes millions of premature deaths worldwide (Silva et al., 2013), and is linked to respiratory infections,

\footnotetext{
${ }^{*}$ Corresponding author.

Tel.: +66-81-882-6988

E-mail address: pwiwatanadate@gmail.com

** Corresponding author.

Tel.: +886-6-266-0208; Fax: +886-6-266-9090

E-mail address: mtsaiyi@mail.cnu.edu.tw
}

heart disease, chronic obstructive pulmonary disease (COPD), stroke and lung cancer. It is associated with dyspnea, wheezing, coughing and asthma (WHO, 2014; Kallawicha et al., 2018; Li et al., 2018) because of its identified impact on lung function (Lee et al., 2011; Arblex et al., 2012; Zhou et al., 2016; Wang et al., 2018).

The World Health Organization (WHO) estimated that in 2015, 383,000 deaths worldwide were due to asthma (WHO, 2020). Many studies have found that ambient air pollution causes adverse effects in asthmatic patients, for example, increased respiratory symptoms (Mann et al., 2010; Kelly and Fussell, 2011), worsened lung function (Aekpalakorn et al., 2003), and decreased peak expiratory 
flow rate (PEFR) (Wiwatanadate and Trakultivakorn, 2010; Zhou et al., 2016). PEFR, a spirometry parameter, is the maximum airflow rate accomplished during forced expiration following maximal inspiration (Ray et al., 1993; Quenier et al., 1997; Skladanowski et al., 2016). It is an especially useful measure for detecting airway obstruction early, when screening asthmatic patients and observing the effects of environmental and occupational exposure (Ray et al., 1993). Reduction in PEFR has been related to exposure to high concentrations of air pollutants, particularly among asthmatic patients (Quanjer et al., 1997; Hong et al., 2010; Wiwatanadate and Trakultivakorn, 2010; Wiwatanadate and Liwsrisakun, 2011; Yamazaki et al., 2011).

The Health Effects Institute (HEI) reported that particulate matter $(\mathrm{PM})$ and ozone $\left(\mathrm{O}_{3}\right)$ are the worst threat toward good air quality in the Asian region (HEI, 2010). PM, a complex mixture of extremely small particles and liquid droplets consisting of organic chemicals, acids, and soil and dust particles (U.S. EPA, 2018), is designated as inhalable $\mathrm{PM}$ of aerodynamic diameter $\leq 10 \mu \mathrm{m}\left(\mathrm{PM}_{10}\right)$ or $\mathrm{PM}$ of aerodynamic diameter $\leq 2.5 \mu \mathrm{m}\left(\mathrm{PM}_{2.5}\right.$ or fine $\left.\mathrm{PM}\right)$. Most PM occurs naturally in the environment, but increasing anthropogenic interferences in the environment have significantly increased the PM burden (Cha et al., 2019). Anthropogenic sources of PM include vehicular emissions and activities such as biomass burning, industrial processing, agricultural operations, and construction activities (Fang et al., 2017; Widiana et al., 2017; Deshmukh et al., 2019; Hao et al., 2019; Hien et al., 2019; Hu et al., 2019; Liu et al., 2019; Shahid et al., 2019). PM emitted from natural sources and human activities includes carbon monoxide (CO), nitrogen dioxide $\left(\mathrm{NO}_{2}\right)$ and sulfur dioxide $\left(\mathrm{SO}_{2}\right)$.

In Thailand, high $\mathrm{PM}_{10}$ concentrations contribute greatly to air pollution, which causes the country significant public health problems. In 2012, Saraburi Province, near Bangkok, recorded the highest $\mathrm{PM}_{10}$ concentration in the country, owing to the stone milling and crushing activity carried out in the area, while areas in the north of the country had the second-highest concentration, due to its annual smog crisis linked to power plant emissions, post-harvest burning, forest fires, and vehicle exhaust fumes (Thepnuan et al., 2019). The problem has been worsening over time as concentrations of $\mathrm{PM}_{10}$ have been increasing continually in every province of Thailand (PCD, 2013). In addition to forest fires, agricultural waste burning, vehicle exhaust emissions, construction work sites and industrial pollution, certain weather conditions are implicated: Temperature inversions and little or no wind helps smog to settle and remain in one place. The northern provinces of Thailand, for example, Chiang Mai, Chiang Rai, Mae Hong Son and Tak, bordering Laos and/or Myanmar, also often suffer pollution that originates from those countries (PCD, 2013; Thepnuan et al., 2019). These diverse causes of smog in the northern provinces produce long- and short-term ill effects among the population. Experimental exposure to PM results in oxidative stress, airway hyper-responsiveness, and airway remodeling, either alone or in combination with allergic sensitization (Stanek et al., 2011), while short-term exposure to ambient $\mathrm{PM}_{2.5}$ and $\mathrm{PM}_{10}$ in asthmatic children and adults has been associated with asthma symptoms, especially in children with allergic sensitization (Weinmayr et al., 2009; Mann et al., 2010; Meng et al., 2010). Longterm exposure to PM is associated with poorly controlled asthma and decrements in lung function in children and adults (Weiss and Ware, 1996; Liu et al., 2009; Jacque et al., 2012). A study in northern Thailand during 2001 and 2002 found that $3.01 \%$ of $22-24$-year-olds had asthma (Dejsomritrutai et al., 2006). The adverse environmental effects have not only damaged human physical and mental health, but also crops and livestock (Boonlong, 2011).

The northern province of Lampang ranks fourth in the most air-polluted provinces in Thailand, with an average maximum daily $\mathrm{PM}_{10}$ of $237 \mu \mathrm{g} \mathrm{m}^{-3}$, and an average that exceeds the standard level for 23 days a year (PCD, 2013). Within Lampang is Mae Moh district, located in a flat valley that is highly prone to temperature inversions, and also home to a coal-fired steam power plant. The Mae Moh Power Plant uses lignite mined from an open pit (EGAT, 2020). In 1992 and 1998, the plant was involved in major environmental disputes, due to local villagers being exposed to sulfur dioxide released from the power plant, with further disputes since then. Thus, the main sources of air pollution in this area include power plant emissions, post-harvest burning, forest fires, and vehicle exhaust fumes. This study aimed to investigate the effects of air pollutants on daily PEFR in people suffering from asthma living in Mae Moh district in Thailand. A longitudinal design of 1-year duration was used, with 33 participants, producing a sample size of 12,045 person-days, making this among the largest pollutionasthma panel studies ever carried out. Also, the use of time series analysis exposed the strongest lagged effect of each pollutant and on PEFR.

\section{MATERIALS AND METHODS}

\section{Study Design, Setting, and Participants}

This study used a panel study design for obtaining a time series of repeated outcome measurements and exposures in a closed cohort of 33 adult sufferers of asthma. All 33 (1) had asthma as diagnosed by a physician, (2) experienced asthma symptoms during the past year, (3) were more than 15 years old, and (4) had lived in Mae Moh district for more than 1 year. In addition, all of the participants lived no farther than $25 \mathrm{~km}$ from the Mae Moh air quality monitoring station, from which most air quality data was collected. The study protocol was approved by the Research Ethics Committee of the Faculty of Medicine, Chiang Mai University (CMU-REC No. 270/2015). All of the participants signed an informed consent form before the study began. Data on participants was collected through structured interviews with the principal researcher and questionnaires requesting demographic characteristics, history of illnesses and allergies, and medication used. The participants additionally had a chest X-ray (CXR) and lung function test. The CXR showed no trace of cancer, empyema, emphysema or COPD for any of the 33 participants. All participants were non-smokers or had quit smoking more than 1 year earlier. Each participant was categorized for the severity of their asthma in accordance with the criteria of the U.S. National Heart, Lung, and Blood 
Institute (NHLBI, 1997; GINA, 2008).

In orientation, participants were taught individually how to measure their own PEFR and asked to repeat the procedure to confirm that they could do it successfully. Each participant measured their PEFR 3 times and the highest and best value was recorded. The study commenced on 2 November 2015 and completed on 31 October 2016. Every day during the study, each participant recorded their PEFR twice when they woke in the morning and before bed in the evening. The PEFR was measured using a Mini Wright Peak Flow Meter (Clement Clarke International, Ltd., UK). Records of the participants were returned to the researcher at the end of each month, and the researcher also accessed data from participants' hospital visits during the study period.

\section{Measurements of Air Pollutants and Meteorological Data}

Data for $\mathrm{NO}_{2}, \mathrm{O}_{3}, \mathrm{SO}_{2}, \mathrm{PM}_{2.5}$ and $\mathrm{PM}_{10}$ were collected from Mae Moh subdistrict air monitoring station, and $\mathrm{CO}$ data were collected from Sob-pad air quality monitoring station, both stations belonging to the Pollution Control Department, Thailand (PCD, 2013). At these automated air sampling monitoring stations, the concentrations of each pollutant are monitored continuously and reported hourly. $\mathrm{CO}$ is analyzed technically using the non-dispersive infrared detection method, $\mathrm{SO}_{2}$ by pararosaniline, $\mathrm{NO}_{2}$ and $\mathrm{O}_{3}$ by chemiluminescence, and $\mathrm{PM}_{10}$ and $\mathrm{PM}_{2.5}$ by the gravimetric method (Air Quality and Noise Management Bureau, PCD, Thailand, 2020). Daily average concentrations (00:00-24:00) were computed, and the highest hourly concentration taken as the daily maximum. Meteorological data, including wind speed, temperature, global radiation, and rainfall quantity, were also collected from the PCD stations. Readings of pressure and relative humidity were taken from measurements at Lampang Airport, which is approximately $30 \mathrm{~km}$ southwest of the study area (Lampang Meteorological Station). The meteorological and pollutant parameters were computed in the same way, except for pressure and relative humidity, which were based on the daily average and daily maximum data from the Lampang Meteorological Station.

\section{Statistical Analysis}

Data on demographic background, and daily meteorological and air pollutant measurements were used to investigate the relationship between concentrations of air pollutants and PEFR by using the generalized estimating equation (GEE) model, which allowed this study to account for the withinsubject correlation of repeated measurements. All pollutant variables were recorded as a time series, and it was assumed that their effects were lagged (delayed). Lag is the delayed effect. The number means the number of days that the effect is delayed. For example, "NO 2 (lag 4)" means that the $\mathrm{NO}_{2}$ data is the $\mathrm{NO}_{2}$ level reported 4 days prior to the data it is being related to. The statistical software used in the analysis was SPSS version 22 (IBM, Singapore).

The steps of analysis were as follows:

1) Separate univariate analysis of mean and maximum levels of the meteorological variables was performed (at lags of 0-6) with three separate measurements of PEFR, morning PEFR, evening PEFR, and daily average PEFR ((morning PEFR + evening PEFR)/2), resulting in a total of three reported outcomes. 2) Each of the mean and maximum ("max") pollutants (lags 0-6) were (univariately) analyzed separately with each outcome. The best lagged effect (i.e., the smallest $p$-value) was entered into the proceeding steps. 3) Demographic factors (gender, age, asthma severity, weight, and height) and day of the week were included in the model, together with the best lagged meteorological covariates for each outcome from the previous step. Those with a $p$-value $<0.25$ were kept for further analysis (Wiwatanadate and Trakultivakorn, 2010). Selection of the 0.25 level was made by following the work of Bendel and Afifi (1977), which showed that use of a more conventional level (e.g., 0.05) often fails to identify variables that are considered important. Due to the autocorrelation nature of repeated measurements over time, this study produced plots of the autocorrelation functions (ACF) (Fig. 1) and partial autocorrelation functions (PACF) (Fig. 2) of all three PEFR outcomes, in order to visualize the characteristics of the correlation: There was an exponential decay pattern for all of the outcome variables, starting at lag 1, in both ACF and PACF plots, indicating that the appropriate structure was first-order autoregressive (StatSoft, Inc., 2007). An autocorrelation plot shows the value of the autocorrelation function on the vertical axis. It can range from -1 to 1 . The horizontal axis of the plot shows the size of the lag between the elements of the time series. 4) All demographic data were applied to all meteorological variables for analysis of each outcome, with $p$-value $<0.25$ from Step 3 and the best lag of each pollutant from Step 2 . 5) If more than one pollutant was found to be statistically significant, the pollutants were chosen and adjusted with a demographic and meteorological variable. 6) The correlation structure with the smallest quasi-likelihood under the independence model criterion (QIC) was selected. 7) The parsimonious model was chosen by the lesser value of quasi-likelihood under the independence model criterion (QICC) (Pan, 2001; Cui and Qian, 2007).

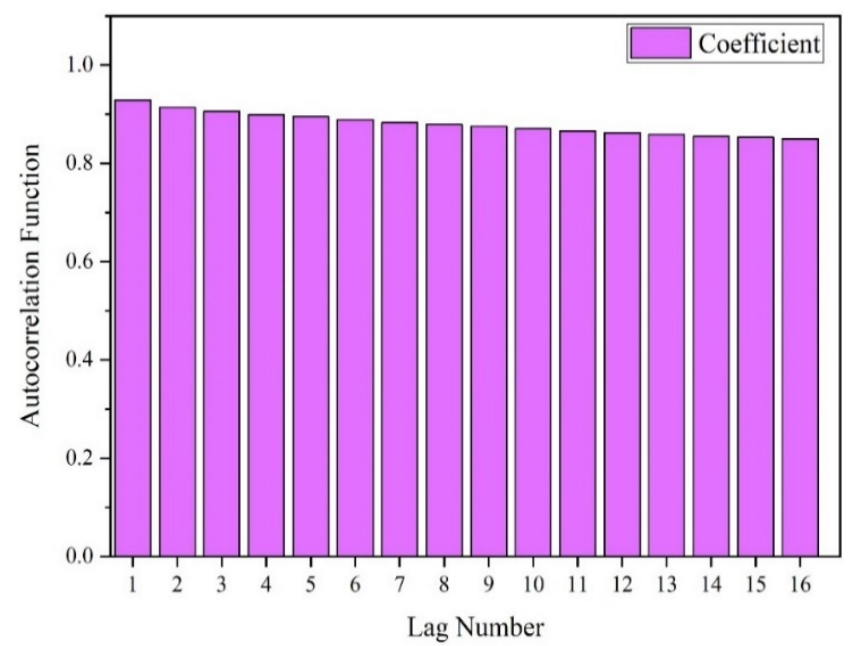

Fig. 1. Autocorrelation function plot of daily morning PEFR of 33 asthmatic patients in Mae Moh district, Lampang, Thailand. 


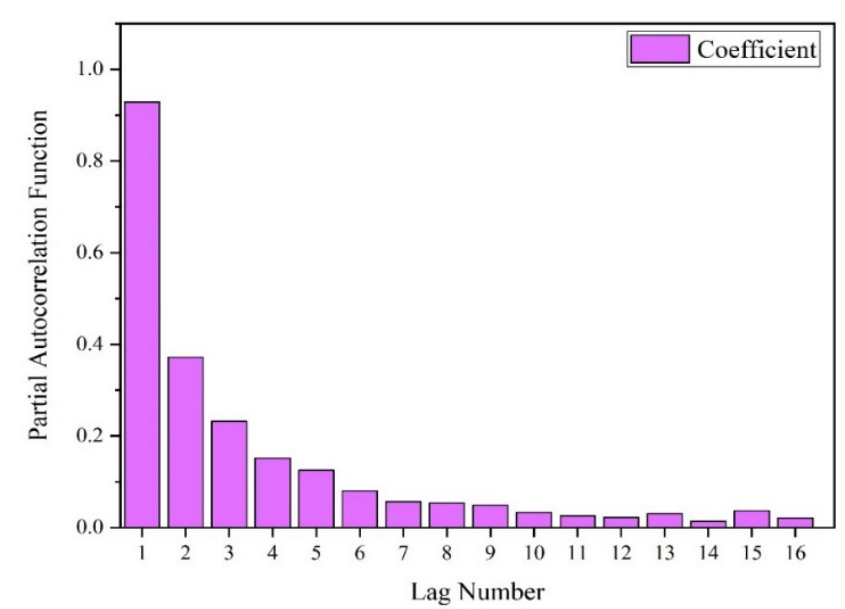

Fig. 2. Partial autocorrelation function plot of daily morning PEFR of 33 asthmatic patients in Mae Moh district, Lampang, Thailand.

\section{RESULTS}

\section{Demographic and Asthma Characteristics of the Cohort}

The asthma severity classification according to the Global Initiative for Asthma (GINA, 2008) were categorized into 4 levels: intermittent, mild persistent, moderate persistent and severe persistent (Bateman et al., 2008). Table 1 presents descriptive statistics of the demographic and asthma characteristics of the cohort. After 4 participants withdrew from this study, 33 remained (11 males and 22 females). Their mean age was $49.4 \pm 10.0$ years, mean body weight, $63.2 \pm 13.1 \mathrm{~kg}$ and mean height, $157.1 \pm 6.2 \mathrm{~cm}$, and their asthma severity was categorized as intermittent $(13 ; 39.4 \%)$, mild persistent $(11 ; 33.3 \%)$ and moderate persistent $(9$; $27.3 \%)$.

\section{Description of Ambient Pollutants}

Concentrations of $\mathrm{NO}_{2}, \mathrm{O}_{3} \mathrm{CO}, \mathrm{SO}_{2}, \mathrm{PM}_{10}$, and $\mathrm{PM}_{2.5}$ were collected daily for the 365 days of the study. Due to monitoring equipment malfunction, records for $\mathrm{NO}_{2}, \mathrm{O}_{3}$ and CO were missing for 17 days $(4.66 \%), 3$ days $(0.82 \%)$ and

Table 1. Descriptive statistics of 33 asthmatic patients in Mae Moh district, Lampang, Thailand, 2 November 201531 October 2016.

\begin{tabular}{ll}
\hline Demographic Data & Value \\
\hline No. males/females & $11 / 22$ \\
Mean age (years) & $49.4(10.0)^{\mathrm{a}}$ \\
Mean weight $(\mathrm{kg})$ & $63.2(13.1)^{\mathrm{a}}$ \\
Mean height $(\mathrm{cm})$ & $157.1(6.2)^{\mathrm{a}}$ \\
Asthma severity (\%) & $13(39.4)^{\mathrm{b}}$ \\
Intermittent & $11(33.3)^{\mathrm{b}}$ \\
Mild persistent & $9(27.3)^{\mathrm{b}}$ \\
Moderate persistent & 0 \\
Severe persistent & \\
a The number in parentheses is standard deviation. \\
${ }^{\mathrm{b}}$ The number in parentheses is the frequency of each \\
category.
\end{tabular}

2 days $(0.55 \%)$, respectively. The daily average concentrations were $4.87 \mathrm{ppb}, 1.28 \mathrm{ppb}, 33.92 \mathrm{ppb}, 49.09 \mu \mathrm{g} \mathrm{m}^{-3}, 28.91$ $\mu \mathrm{g} \mathrm{m}^{-3}$ and $0.76 \mathrm{ppm}$ for $\mathrm{NO}_{2}, \mathrm{SO}_{2}, \mathrm{O}_{3}, \mathrm{PM}_{10}, \mathrm{PM}_{2.5}$, and $\mathrm{CO}$, respectively. The meteorological daily averages were $0.98 \mathrm{~m} \mathrm{~s}^{-1}$ for wind speed, $26.03^{\circ} \mathrm{C}$ for temperature, $72.4 \%$ for relative humidity, $163.14 \mathrm{w} \mathrm{m}^{-2}$ for global radiation, $1009.96 \mathrm{mbar}$ for pressure and $0.14 \mathrm{~mm}$ for rain quantity.

Daily mean and max pollutants and meteorological parameters are shown in Table 2 . The daily average $\mathrm{PM}_{10}$ and $\mathrm{PM}_{2.5}$ concentration exceeded the Thai standard concentrations of $120 \mu \mathrm{g} \mathrm{m}^{-3}$ and $50 \mu \mathrm{g} \mathrm{m}^{-3}$ for 18 days and 76 days, respectively.

Table 3(a) shows the correlation matrix of mean ambient air pollutants and mean meteorological parameters. The highest correlation of ambient air pollutants was that between $\mathrm{PM}_{10}$ and $\mathrm{PM}_{2.5}, \mathrm{r}=0.981$.

Table 3(b) shows the correlation matrix of max ambient air pollutants and max meteorological parameters. The highest correlation of max ambient air pollutants was that between $\mathrm{PM}_{10}$ max and $\mathrm{PM}_{2.5} \max , \mathrm{r}=0.918$.

\section{Association between Daily Average Pollutant Levels and PEFR}

Morning PEFR

A separate single-pollutant model was performed, and adjustments to each best-lagged pollutant made for gender, asthma severity, day of the week, age, weight, wind speed (lag 5), temperature (lag 1), global radiation (lag 4), pressure (lag 1) and rain quantity (lag 6). It was found that $\mathrm{NO}_{2}$ (lag 4) associated positively with morning PEFR, with a coefficient of 0.23 (95\% confidence interval [CI]: 0.03 , 0.43). $\mathrm{PM}_{10}$ (lag 6) and $\mathrm{CO}$ (lag 6) associated negatively with morning PEFR, with coefficients of -0.05 (95\% CI: $-0.07,-0.02)$ and -3.93 (95\% CI: $-7.43,-0.43)$, respectively. The multi-pollutant models were analyzed further with all possible combinations of pollutants from the single-pollutant model [excluding $\mathrm{SO}_{2}$ (lag 4), $\mathrm{O}_{3}$ (lag 3) and $\mathrm{PM}_{2.5}$ (lag 6)]. It was found that the ambient daily mean concentration of $\mathrm{NO}_{2}$ (lag 4) associated positively with morning PEFR, with a coefficient of 1.34 (95\% CI: $0.25,2.44)$. This meant that an increase of $1 \mathrm{ppb}$ in the daily mean ambient concentration of $\mathrm{NO}_{2}$ (lag 4) was associated with an increase in morning PEFR of $1.34 \mathrm{~L} \mathrm{~min}^{-1}$. Meanwhile, $\mathrm{NO}_{2}$ (lag 4) and $\mathrm{PM}_{10}$ (lag 6) $\left[\mathrm{NO}_{2}\right.$ (lag 4) $\times \mathrm{PM}_{10}$ (lag 6)] associated negatively with a coefficient of -0.015 (95\% CI: $-0.030,-0.001)$. This meant that the interaction between the daily mean concentration of $\mathrm{NO}_{2}$ (lag 4) and $\mathrm{PM}_{10}$ (lag 6) associated multiplicatively with a decreased morning PEFR by -0.015 (95\% CI: $-0.030,-0.001$ ) (Table 4).

\section{Evening PEFR}

Evening PEFR was analyzed using the single-pollutant model in the same manner as the method mentioned above. The results showed that there was no statistical significance.

\section{Daily Average PEFR}

The single-pollutant model showed that $\mathrm{NO}_{2}$ (lag 4) was statistically positively related to the daily average PEFR with a coefficient of 0.15 (95\% CI: 0.02, 0.29), while $\mathrm{SO}_{2}$ 

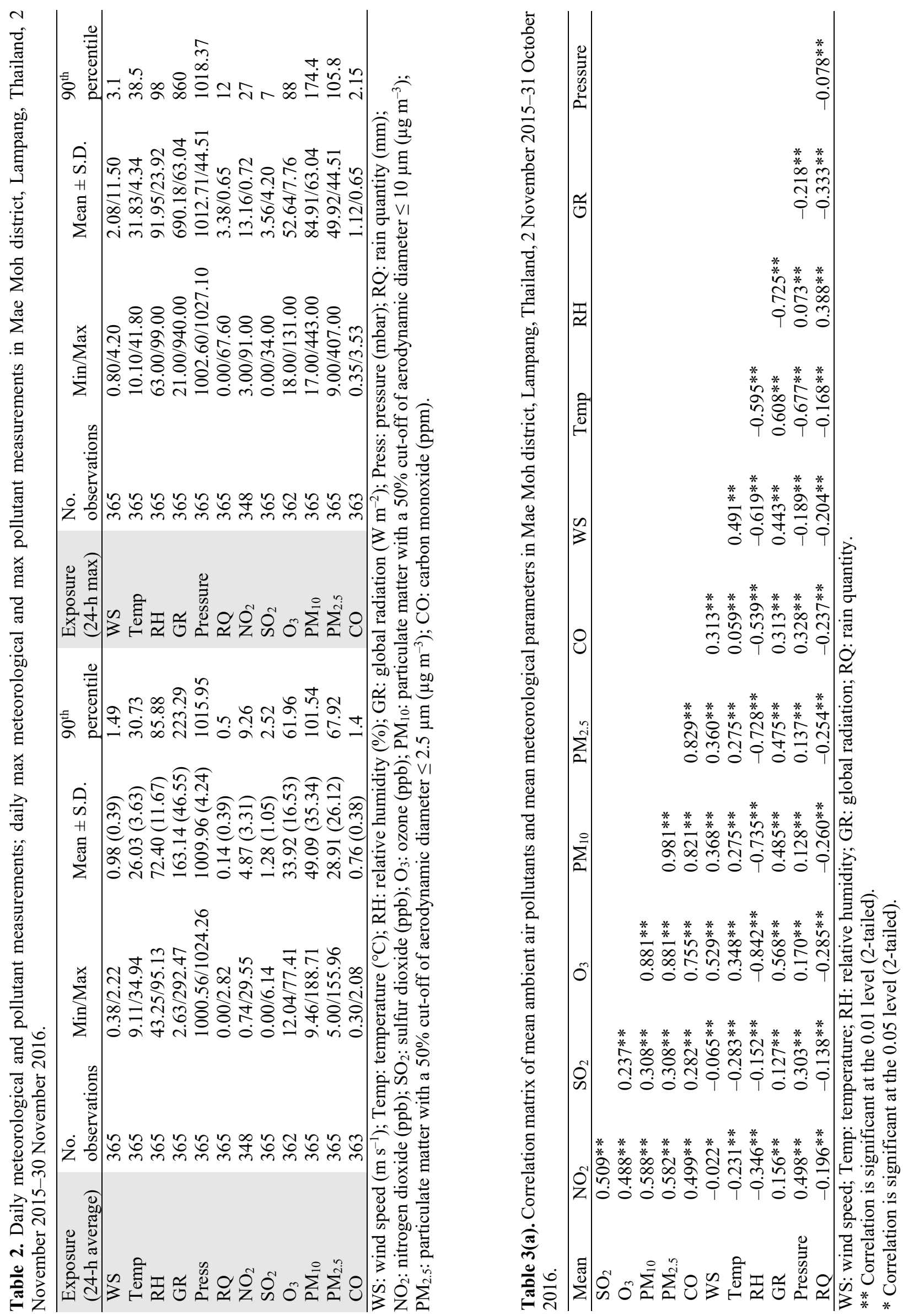

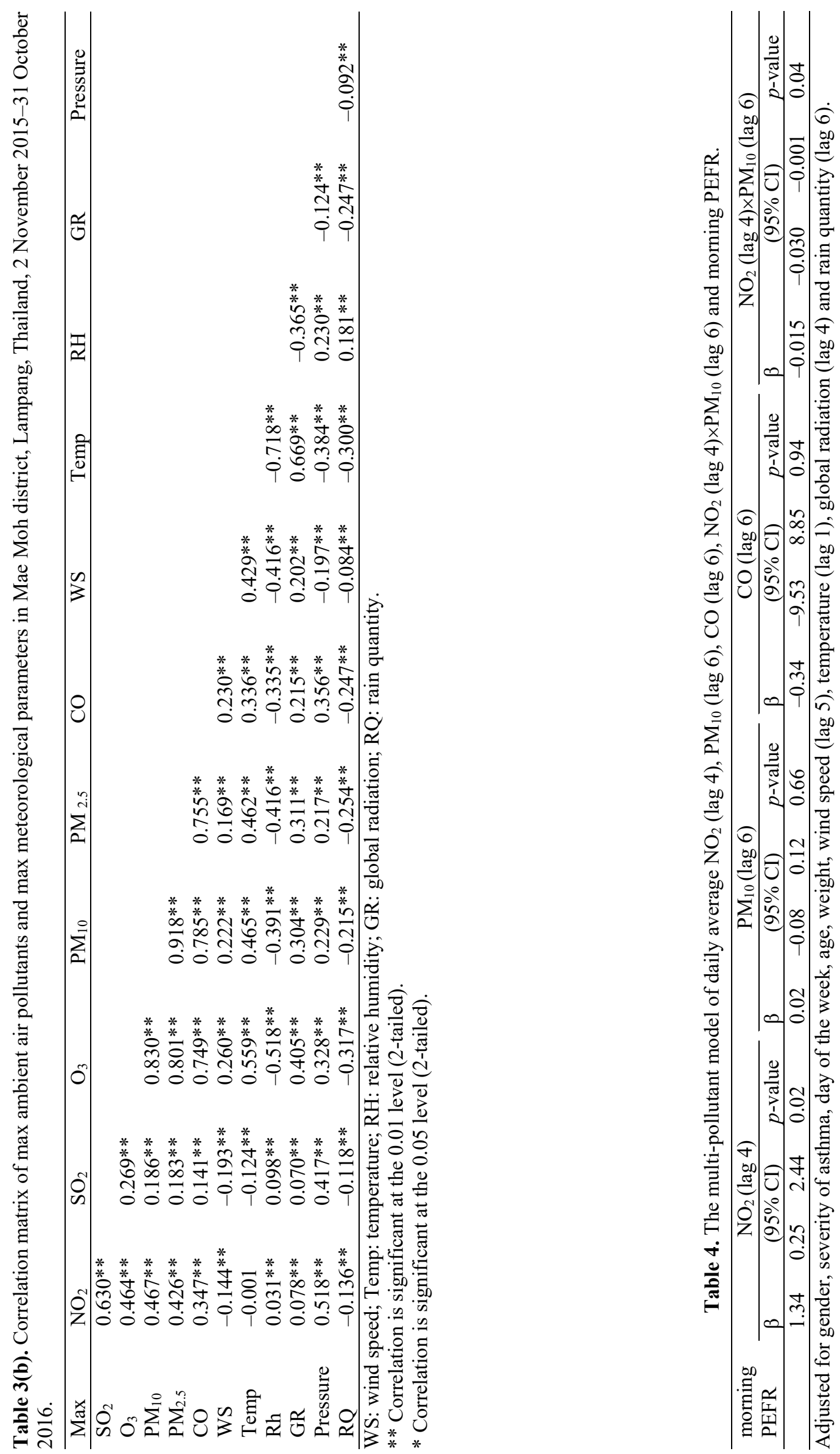
was statistically negatively related to the daily average PEFR with a coefficient of -0.52 (95\% CI: $-1.03,-0.02)$.

The multi-pollutant model showed that $\mathrm{NO}_{2}$ (lag 4) associated positively with PEFR with a coefficient of 0.15 (95\% CI: 0.01, 0.29), while $\mathrm{SO}_{2}$ associated negatively, with a coefficient of -0.47 (95\% CI: $-0.92,-0.01)$ (Table 5).

\section{Association between Daily Maximum Pollutant Levels and PEFR \\ Morning PEFR}

The single-pollutant model showed that $\mathrm{PM}_{2.5}$ max (lag 4) related both statistically and positively to morning PEFR with a coefficient of 0.02 (95\% CI: $0.001,0.04) . \mathrm{NO}_{2} \max$ (lag 2), $\mathrm{PM}_{10} \max (\operatorname{lag} 6$ ) and $\mathrm{CO} \max (\operatorname{lag} 6)$ associated negatively with morning PEFR, with coefficients of -0.07 (95\% CI: $-0.13,-0.01),-0.02$ (95\% CI: $-0.03,-0.01)$, and -1.68 (95\% CI: $-3.08,-0.27)$, respectively. Both PM $_{10}$ and $\mathrm{PM}_{2.5}$ were significant, due to analysis of the single-pollutant model. Analysis of the multi-pollutant model of morning PEFR was made separately for $\mathrm{PM}_{2.5}$ and $\mathrm{PM}_{10}$.

The multi-pollutant model with all possible combinations of pollutants [excluding $\mathrm{SO}_{2} \max$ (lag 4), and $\mathrm{O}_{3} \max (\operatorname{lag} 4)$ ] from the single-pollutant model applied showed that $\mathrm{NO}_{2}$ max (lag 2) and CO max (lag 6) were negatively related to morning PEFR with coefficients of -0.08 (95\% CI: -0.14 ,
$-0.02)$ and $-1.71(95 \%$ CI: $-3.11,-0.30)$, respectively (Table 6(a)).

$\mathrm{NO}_{2}$ max (lag 2) and $\mathrm{PM}_{10} \max$ (lag 6) associated negatively with coefficients of -0.07 (95\% CI: $-0.13,-0.01)$ and -0.013 (95\% CI: $-0.024,-0.002$ ), respectively (Table 6(b)).

\section{Evening PEFR}

The single-pollutant model showed that $\mathrm{O}_{3} \max (\operatorname{lag} 3$ ) and $\mathrm{PM}_{2.5}$ max associated positively with evening PEFR, with coefficients of 0.09 (95\% CI: $0.04,0.14)$ and 0.03 (95\% CI: 0.01, 0.05), respectively. The multi-pollutant model, with all possible combinations of pollutants [excluding $\mathrm{NO}_{2} \max$ (lag 1), $\mathrm{SO}_{2} \max$ (lag 5), $\mathrm{PM}_{10}$ max (lag 3), and $\mathrm{CO} \max$ (lag 1)] from the single-pollutant model showed that both $\mathrm{O}_{3}$ max (lag 3) and $\mathrm{PM}_{2.5}$ max were positively associated with evening PEFR with coefficients of 0.098 (95\% CI: 0.03 , 0.127 ) and 0.029 (95\% CI: 0.007, 0.051) (Table 7).

\section{Daily Average PEFR}

The single-pollutant model showed that $\mathrm{NO}_{2} \max$ (lag 2) associated negatively with daily average PEFR, with a coefficient of -0.05 (95\% CI: $-0.10,-0.01)$, while $\mathrm{O}_{3}$ max (lag 3 ) associated positively with daily average PEFR, with a coefficient of 0.05 (95\% CI: $0.02,0.08)$. The multipollutant model with all possible combinations of pollutants

Table 5. The multi-pollutant model of daily average $\mathrm{NO}_{2}$ (lag 4), $\mathrm{SO}_{2}$ and daily average PEFR.

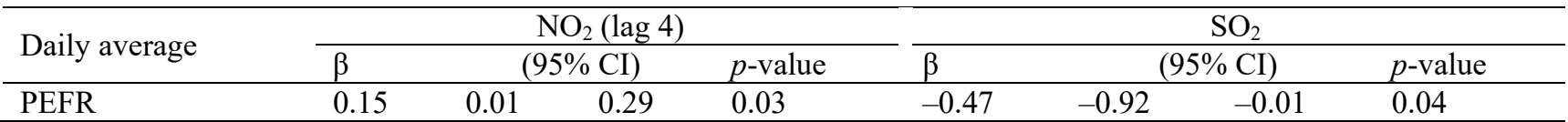

Adjusted for gender, severity of asthma, day of the week, age, weight, wind speed (lag 5), temperature (lag 1), global radiation (lag 4), pressure (lag 1) and rain quantity (lag 2).

Table 6(a). The multi-pollutant model of daily average $\mathrm{NO}_{2} \max (\operatorname{lag} 2), \mathrm{PM}_{2.5} \max (\operatorname{lag} 4)$, $\mathrm{CO} \max (\mathrm{lag} 6)$ and morning PEFR.

\begin{tabular}{|c|c|c|c|c|c|c|c|c|c|c|}
\hline \multicolumn{4}{|c|}{$\mathrm{NO}_{2} \max (\operatorname{lag} 2)$} & \multicolumn{4}{|c|}{$\mathrm{PM}_{2.5} \max (\operatorname{lag} 4)$} & \multicolumn{3}{|c|}{$\mathrm{CO} \max (\operatorname{lag} 6)$} \\
\hline$\beta$ & & $0 \mathrm{CI})$ & $p$-value & $\beta$ & & CI) & $p$-value & $\beta$ & & $p$-value \\
\hline-0.08 & -0.14 & -0.02 & 0.01 & 0.016 & -0.003 & 0.036 & 0.105 & -1.71 & -3.11 & 0.02 \\
\hline
\end{tabular}

Adjusted for gender, asthma severity, day of the week, age, weight, wind speed max (lag 6), temperature max (lag 4), relative humidity max (lag 1), global radiation max (lag 4), pressure max (lag 1) and rain quantity max (lag 6).

Table 6(b). The multi-pollutant model of daily average $\mathrm{NO}_{2} \max$ (lag 2), $\mathrm{PM}_{10} \max$ (lag 6), $\mathrm{CO}$ max (lag 6), and morning PEFR.

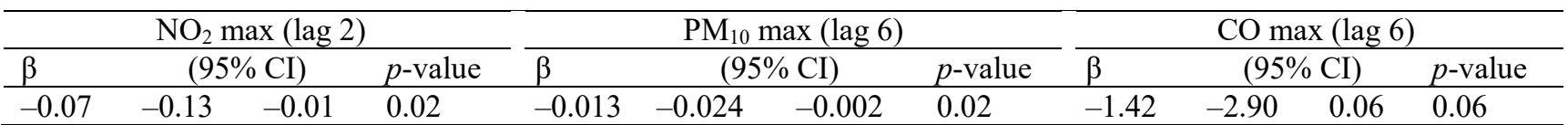

Adjusted for gender, asthma severity, day of the week, age, weight, wind speed max (lag 6), temperature max (lag 4), relative humidity max (lag 1), pressure max (lag 1 ) and rain quantity max (lag 6).

Table 7. The multi-pollutant model of $\mathrm{O}_{3} \max (\operatorname{lag} 3), \mathrm{PM}_{2.5} \max$ and evening PEFR.

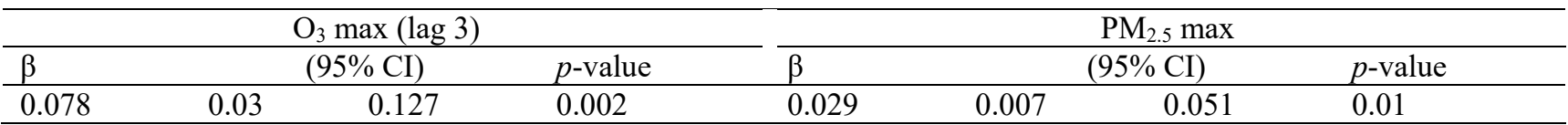

Adjusted for gender, asthma severity, age, weight, global radiation max (lag 1), pressure max (lag 1) and rain quantity max (lag 5). 
[excluding $\mathrm{SO}_{2} \max (\operatorname{lag} 4), \mathrm{PM}_{10} \max , \mathrm{PM}_{2.5} \max$, and $\mathrm{CO}$ max] from the single-pollutant model showed that $\mathrm{NO}_{2}$ max (lag 2) was negatively related to daily average PEFR with a coefficient of $-0.05(95 \% \mathrm{CI}:-0.10,-0.01)$, and $\mathrm{O}_{3} \max$ (lag 3) was positively related to daily average PEFR with a coefficient of 0.06 (95\% CI: 0.02, 0.09) (Table 8).

\section{DISCUSSION}

A negative relationship between pollutant level and PEFR allows for the possibility that the pollutant harms PEFR. It follows that a positive relationship between pollutant level and PEFR allows for the possibility that the pollutant improves PEFR. In this study, the following negative relationships were found: $\mathrm{NO}_{2}$ max (lag 2) was found to be related negatively to both morning and daily average PEFR, and $\mathrm{SO}_{2}$ was related negatively to daily average PEFR. $\mathrm{PM}_{10}$ max (lag 6) appeared to associate negatively with morning PEFR. Also, CO max (lag 6) was negatively associated with morning PEFR. Conversely, $\mathrm{NO}_{2}$ (lag 4) had a consistently positive association with morning and daily average PEFR, and $\mathrm{O}_{3}$ max (lag 3) was found to relate positively to daily average PEFR.

When inhaled, $\mathrm{NO}_{2}$ penetrates to the trachea, bronchi, bronchiole, and alveoli and is an irritant to the mucosa of the eyes, nose, throat, and lower respiratory tract. It also increases bronchial reactivity and increases susceptibility to infections and allergens. It is considered a good marker of vehicular pollution (Arbrex et al., 2013). The finding in the present study that $\mathrm{NO}_{2}$ (lag 4) had a consistently positive association with morning and daily average PEFR was at odds with its "pollutant" status and was contradictory to the results of most other studies, which show an inverse association between $\mathrm{NO}_{2}$ and PEFR (Pekkanen et al., 1997; Timonen and Pekkanen, 1997; Castro et al., 2009; Qian et al., 2009). Meanwhile, in some studies, no link has been found between $\mathrm{NO}_{2}$ and PEFR (van der Zee et al., 2000; Kwon et al., 2007; Amadeo et al., 2015). As in the present study, Wiwatanadate and Trakultivakorn (2010) found that $\mathrm{NO}_{2}$ (lag 5) associated positively with morning PEFR. Although $\mathrm{NO}_{2}$ (lag 4) in the present study was associated statistically, significantly and positively with morning and daily average PEFR, the interaction of $\mathrm{NO}_{2}$ (lag 4) and $\mathrm{PM}_{10}$ (lag 6) produced a significantly inverse effect on morning PEFR, with a coefficient of -0.015 (95\% CI: $-0.03,-0.001)$ (Table 4). Furthermore, our result showed that $\mathrm{NO}_{2}$ max (lag 2) had a significantly inverse association with morning and average PEFR. Specifically, a $1 \mathrm{ppb}$ increase in $\mathrm{NO}_{2}$ $\max$ (lag 2) with $\mathrm{PM}_{2.5}$ was associated with a morning PEFR decrease of $0.08 \mathrm{~L} \mathrm{~min}^{-1}$ (Table 6(a)), while a $1 \mathrm{ppb}$ increase in $\mathrm{NO}_{2}$ max (lag 2) with $\mathrm{PM}_{10}$ was associated with a morning PEFR decrease of $0.07 \mathrm{~L} \mathrm{~min}^{-1}$ (Table 6(b)). A $1 \mathrm{ppb}$ increase in $\mathrm{NO}_{2}$ max (lag 2) was associated with an average PEFR decrease of $0.05 \mathrm{~L} \mathrm{~min}^{-1}$ (Table 8). These results show that $\mathrm{NO}_{2}$ max (lag 2) had a significant inverse association with morning and daily average PEFR and indicate a potential harmful effect of this pollutant. It is possible that $\mathrm{NO}_{2}$ enhances lung function at very low doses, while high doses reduce lung function. Studies have tended to conclude that significant inverse association between air pollutants and PEFR exists at high pollutant concentrations (Wichmann and Heinrich, 1995), while no significant associations exist at low dose exposures (Kwon et al., 2007).

This study found that $\mathrm{O}_{3}$ max (lag 3) had a consistently positive association with daily average PEFR, and $\mathrm{O}_{3}$ appeared to be a protective factor in enhancing PEFR. It is known that some toxic agents can be beneficial to health at a low dose, such as bacterial endotoxins, which help to decrease the risk of asthma in children (Obihara et al., 2007; Sordillo et al., 2010), and lifelong exposure to farms may effectively reduce asthma risk in adults (Douwes et al., 2007). Regarding $\mathrm{O}_{3}$, the results in the present study are in agreement with a study in Brazil showing that a $10 \mu \mathrm{g} \mathrm{m}^{-3}$ increase in $\mathrm{O}_{3}$ (lag 1) enhanced morning PEFR by $0.2 \mathrm{~L} \mathrm{~min}^{-1}$ in asthmatic children (Castro et al., 2009). However, other studies have found a negative association between the $\mathrm{O}_{3}$ concentrations and lung function. $\mathrm{O}_{3}$ is one of the most wellstudied air pollutants, with initial speculation about health effects dating to the mid-nineteenth century (Rohr, 2018). $\mathrm{O}_{3}$ exposure results in airway inflammation, airway hyperresponsiveness, and decrements in lung function in healthy and asthmatic adults (Seltzer et al., 1986). Schachter et al. (2016) evaluated asthmatic children in New York and found that $\mathrm{O}_{3}$ was associated with decreased forced expiratory volume in 1 second $\left(\mathrm{FEV}_{1}\right)$ in summer. A panel study of Australian children, who had bronchial hyperactivity and asthma, revealed a significant inverse association between mean daytime $\mathrm{O}_{3}$ and mean daily deviation in the PEFR (coefficient $=-2.61$ and $p$-value $=0.001)$ (Jalaludin et al. 2000). However, a study of children in northern France found that this association was not significant (Declercq et al., 2000). Dales et al. (2009) similarly found no significant associations for ozone concentration and $\mathrm{FEV}_{1}$, and Samoli et al. (2017) followed 186 children for 5 weeks and found that personal ozone exposure was not associated with PEFR.

$\mathrm{SO}_{2}$ penetrates into upper airways, trachea, bronchi, and bronchioles, and affects the mucosa of the eyes, nose, throat, and respiratory tract. It causes cough and increases bronchial reactivity, facilitating bronchoconstriction (Arbex et al., 2012). In the present study, a mean daily increase of $1 \mathrm{ppb}$ of $\mathrm{SO}_{2}$ was associated with a decrease in daily average PEFR of

Table 8. The multi-pollutant model of daily average $\mathrm{NO}_{2} \max (\operatorname{lag} 2), \mathrm{O}_{3}$ max (lag 3) and daily average PEFR.

\begin{tabular}{|c|c|c|c|c|c|c|c|}
\hline \multicolumn{4}{|c|}{$\mathrm{NO}_{2} \max (\operatorname{lag} 2)$} & \multicolumn{4}{|c|}{$\mathrm{O}_{3} \max (\operatorname{lag} 3)$} \\
\hline$\beta$ & & CI) & $p$-value & $\beta$ & & CI) & $p$-value \\
\hline-0.05 & -0.10 & -0.01 & 0.02 & 0.06 & 0.02 & 0.09 & 0.01 \\
\hline
\end{tabular}

Adjusted for gender, asthma severity, day of the week, age, weight, wind speed max (lag 6), temperature max (lag 4) and pressure max (lag 1). 
$0.47 \mathrm{~L} \mathrm{~min}^{-1}$. Once again, the literature offers other works that also reported a negative association (Qian et al., 2009; Wiwatanadate and Trakultivakorn, 2010), and those that report no association between $\mathrm{SO}_{2}$ and PEFR (Aekplakorn et al., 2003; Park et al., 2005; Uno et al., 2005; Canova et al., 2010). It is noteworthy that $\mathrm{SO}_{2}$ appeared to have adverse effects on lung function in adult asthmatic patients in the present study even though the 24-h average levels of $\mathrm{SO}_{2}$ never exceeded the standard value for Thailand of $120 \mathrm{ppb}$ during the study period.

This study found that CO max (lag 6) associated negatively with morning PEFR, with a coefficient of -1.71 (95\% CI: $-3.1,-0.30$ ) (Table 6(a)); a 1 ppm increase of daily ambient CO max (lag 6) was associated with a decrease in morning PEFR of $1.71 \mathrm{~L} \mathrm{~min}^{-1}$. This result supports previous works: Park et al. (2005) found that in a panel of 64 asthmatic adults, $\mathrm{CO}$ associated negatively with PEFR variability and mean daily average PEFR; Penttinen et al. (2001) found that $\mathrm{CO}$ associated negatively with daily average, morning and evening PEFR in adult asthmatic patients; Canova et al. (2010) revealed that CO negatively associated with morning and evening PEFR in adult asthmatic patients.

Regarding $\mathrm{PM}_{2.5}$ and $\mathrm{PM}_{10}$, epidemiological studies suggest that $\mathrm{PM}_{2.5}$ may exert greater toxicity than larger particles (Xing et al., 2016). Toxicological studies have demonstrated that PM exposure may impact respiratory health by inducing both lung inflammation and systemic inflammation (Li et al., 2017; Maciejczyk et al., 2018).

Various studies have found an association between $\mathrm{PM}_{2.5}$ concentrations and decreased lung function (Li et al., 2017; Wang et al., 2018; Huang et al., 2019; Rahma et al., 2019) but this was not the case in this study, even when ambient $\mathrm{PM}_{2.5}$ levels frequently exceeded the U.S. NAAQS during the study period. This was not surprising because the causal components and susceptible subgroups of particulate matter are not clear (Delfino et al., 2003). Also, the major sources of air pollution in this study were located in northern Thailand, where there are forest fires and open field burning, which is different from most other studies that relate air pollution to traffic (Wiwatanadate and Liwsrisaku, 2010). Regarding the positive association between $\mathrm{O}_{3}$ max (lag 3), $\mathrm{PM}_{2.5}$ max and evening PEFR, our study showed that $84 \%$ of participants used Budesonide meter dose inhaler (MDI) and Salbutamol MDI. These medications can attenuate the effects of air pollution and PEFR. Peters et al. (1997) found that medication use in asthmatics attenuated the associations between particulate air pollution and PEFR. There may also be other uncontrolled factors affecting this association. $\mathrm{PM}_{10} \max$ (lag 6) associated negatively with morning PEFR, with a coefficient of -0.01 (95\% CI: -0.024 , $-0.002)$. Specifically, a $1 \mu \mathrm{g} \mathrm{m}^{-3}$ increase in daily ambient $\mathrm{PM}_{10}$ max (lag 6) was associated with a decrease in morning PEFR of $0.01 \mathrm{~L} \mathrm{~min}$. These results support previous findings (Hoek et al., 1998; Qian et al., 2009; Wiwatanadate and Liwsrisakun, 2011; Missagia et al., 2018). Missagia et al. (2018) studied 117 children and adolescents in a Brazilian public school and found that an increase of $14 \mu \mathrm{g}$ $\mathrm{m}^{-3}$ in $\mathrm{PM}_{10}$ associated with decreased morning PEFR by $1.04 \%$ (95\% CI: $-1.32,-0.77)$. Hoek et al. (1998) analyzed and averaged data from five panel studies and reported an increase of $10 \mu \mathrm{g} \mathrm{m}^{-3}$ in $\mathrm{PM}_{10}$ related to a decrease of $0.07 \%$ in mean PEFR. In the present study, no adverse effects were identified for $\mathrm{PM}_{10}$ and evening PEFR. This may be because airway narrowing/symptoms felt on waking up were immediately recorded by participants (i.e., before taking any remedial action), whereas remedial actions (including self-medication) taken during the day may have alleviated or removed symptoms at the time of the evening PEFR (Pride, 1992; Timonen and Pekkanen, 1997). A systematic review by Ward and Ayres (2004) showed air pollution effects on children. It indicated that $\mathrm{PM}_{2.5}$ produced more adverse effects than $\mathrm{PM}_{10}$, as an increase in $\mathrm{PM}_{2.5}$ and $\mathrm{PM}_{10}$ levels of $10 \mu \mathrm{g} \mathrm{m}^{-3}$ associated with a decrease in PEFR of $0.063 \mathrm{~L} \mathrm{~min}{ }^{-1}$ (95\% CI: $\left.-0.091,-0.034\right)$ and $-0.012 \mathrm{~L} \mathrm{~min}^{-1}$ (95\% CI: $-0.017,-0.008)$, respectively. In contrast, the present study found that $\mathrm{PM}_{10}$ produced more adverse effects than $\mathrm{PM}_{2.5}$.

The main implications of findings reported in this study are, first, that information regarding pollutants' delayed effects will enable the forecasting of health effects and help the concerned health organizations to be prepared for patients in advance of likely increases in demand. Second, knowledge of the negative effects of some pollutants on PEFR will encourage health policy makers to take serious actions to prevent those pollutants at their sources.

\section{Limitation}

The use of a steroid inhaler (Budesonide MDI) and bronchodilator (Salbutamol MDI) by $84 \%$ of the participants in this study could weaken or confound the effects of the pollutants. This is because the use of antiinflammatory medication could either intensify the effects of ambient pollutants on lung function (Lewis et al., 2005) or guard against the pro-inflammatory effects of air pollutants (Delfino et al., 2002). Peter et al. (1997) found that the use of medication in asthmatic patients diminished the association between particulate air pollution and PEFR. Also, existing resources for this study were inadequate for comprehensively taking into account several likely confounding factors such as aeroallergens and indoor air pollution (household dust, cooking fumes, second-hand smoke, or incense smoke) and indoor allergens from pets and working patterns and places. Furthermore, the concentrations of ambient pollutants might not represent the individual's exposure doses due to different physiology.

\section{CONCLUSIONS}

In this study, $\mathrm{SO}_{2}, \mathrm{PM}_{10} \max (\operatorname{lag} 6)$ and $\mathrm{NO}_{2} \max (\operatorname{lag} 2)$ exhibited significant inverse relationships with the PEFR. Also, the interaction between $\mathrm{NO}_{2}$ (lag 4) and $\mathrm{PM}_{10}$ (lag 6) appeared to produce a significantly negative additive effect on the flow rate. Hence, these pollutants, after the specified delays, potentially reduced the PEFR. Conversely, we observed positive associations between several of the species and the flow rate, suggesting that increased concentrations of the former, including $\mathrm{NO}_{2}$ (lag 4) and $\mathrm{O}_{3} \max$ (lag 3), enhanced the latter. As discussed, low concentrations of 
certain pollutants have been reported to potentially increase the PEFR, and other researchers have observed positive as well as negative relationships between supposed "pollutants" and the flow rate. Nonetheless, expecting a positive association between these two parameters is counterintuitive, and we recommend further investigation. Our results also demonstrate that the various species (and meteorological factors) did not necessarily cause identical delayed effects. The combination of $\mathrm{NO}_{2} \max \left(\operatorname{lag} 2\right.$ ) and $\mathrm{PM}_{10} \max (\operatorname{lag} 6$ ), for example, was significantly associated with the decreased morning PEFR, indicating that the effects of both pollutants on lung function require time to manifest.

\section{ACKNOWLEDGMENTS}

This study was funded by the Faculty of Medicine, Chiang Mai University, and the Ministry of Science and Technology, Taiwan, under Grant No. MOST 108-2221-E041-002-MY3. The authors are very thankful for the realtime air monitoring data from the Pollution Control Department, Thailand, and the Northern Meteorology Center, Thailand, for its meteorological data. Special thanks go to all of the asthmatic patients who participated in this study. The authors declare no competing interest.

\section{REFERENCES}

Aekplakorn, W., Loomis, D., Vichit-Vadakan, N., Shy, C., Wongtim, S. and Vitayanon, P. (2003). Acute effect of sulphur dioxide from a power plant on pulmonary function of children, Thailand. Int. J. Epidemiol. 32: 854861. https://doi.org/10.1093/ije/dyg237

Amado, B., Robert, C., Rondeau, V., Mounouchy, M.A., Cordeau, L., Birembaux, X., Citadelle, E., Gotin, J., Gouranton, M., Marcin, G., Laurac, D. and Raherison, C. (2015). Impact of close-proximity air pollution on lung function in schoolchildren in the French West Indies. BMC Public Health 15: 45. https://doi.org/10.1186/s128 89-015-1382-5

Arbex, M.A., Santos, U.P., Martins, L.C., Saldiva, P.H.N., Pereira, L.A.A. and Braga, A.L.F. (2012). Air pollution and the respiratory system. J. Bras. Pneumol. 38: 643-655. https://doi.org/10.1590/S1806-37132012000500015

Bateman, E.D., Hurd, S.S., Barnes, P.J., Bousquet, J., Drazen, J.M., FitzGerald, M., Gibson, P., Ohta, K., O’Byrne, P., Pedersen, S.E., Pizzichini, E., Sullivan, S.D., Wenzel, S.E. and Zar, H.J. (2008). Global strategy for asthma management and prevention: GINA executive summary. Eur. Respir. J. 31: 143-178. https://doi.org/10.1183/09 031936.00138707

Bendel, R.B. and Afifi, A.A. (1977). Comparison of stopping rules in forward "stepwise" regression. J. Am. Stat. Assoc. 72: 46-53. https://doi.org/10.2307/2286904

Boonlong, R. (2011). Energy issues in Thailand. In Representation and decision-Making in environment planning with emphasis on energy technologies, Boonlong, R., Farbotko, C., Parfondry, C., Graham, C. and Macer, D. (Eds.), UNESCO Bangkok, Thailand. pp. 9-26.

Canova, C., Torresan, S., Simonato, L., Scapellato, M.L.,
Tessari, R., Visentin, A., Lotti, M. and Maestrelli, P. (2010). Carbon monoxide pollution is associated with decreased lung function in asthmatic adults. Eur. Respir. J. 35: 266272. https://doi.org/10.1183/09031936.00043709

Castro, H.A., Cunha, M.F., Mendonça, G.A., Junger, W.L., Cunha-Cruz, J. and Leon, A.P. (2009). Effect of air pollution on lung function in schoolchildren in Rio de Janeiro, Brazil. Rev. Saude Publica. 43: 26-34. https://doi.org/10.1590/S0034-89102009000100004

Cha, Y., Tu, M., Elmgren, M., Silvergren, S. and Olofsson, U. (2019). Variation in airborne particulate levels at a newly opened underground railway station. Aerosol Air Qual. Res. 19: 737-748. https://doi.org/10.4209/aaqr.201 8.06.0225

Cui, J. and Qian, G. (2007). Selection of working correlation structure and best model in GEE analyses of longitudinal data. Commun. Stat.-Simul. Comput. 36: 987-996. https://doi.org/10.1080/03610910701539617

Dales, R., Chen, L., Frescura, A.M., Liu, L. and Villeneuve, P.J. (2009). Acute effects of outdoor air pollution on forced expiratory volume in $1 \mathrm{~s}$ : A panel study of schoolchildren with asthma. Eur. Respir. J. 34: 316-323. https://doi.org/10.1183/09031936.00138908

Declercq, C. and Macquet, V. (2000). Short-term effects of ozone on respiratory health of children in Armentières, North of France. Rev. Epidemiol. Sante Publique 48: 2S37-2S43.

Dejsomritrutai, W., Nana, A., Chierakul, N., Tscheikuna, J., Sompradeekul, S. and Ruttanaumpawan, P. (2006). Prevalence of bronchial hyperresponsiveness and asthma in the adult population in Thailand. Chest 129: 602-609. https://doi.org/10.1378/chest.129.3.602

Delfino, R.J., Zeiger, R.S., Seltzer, J.M., Street, D.H. and McLaren, C.E. (2002). Association of asthma symptoms with peak particulate air pollution and effect modification by anti-inflammatory medication use. Environ. Health Perspect. 110: A607-A617. https://doi.org/10.1289/ehp.0 21100607

Delfino, R.J., Gong, H. Jr., Linn, W.S., Pellizzari, E.D. and $\mathrm{Hu}, \mathrm{Y}$. (2003). Asthma symptoms in Hispanic children and daily ambient exposures to toxic and criteria air pollutants. Environ. Health Perspect. 111: 647-656. https://doi.org/10.1289/ehp.5992

Deshmukh, D.K., Kawamura, K., Gupta, T., Haque, M.M., Zhang, Y.L., Singh, D.K. and Tsai, Y.I. (2019). High loadings of water-soluble oxalic acid and related compounds in $\mathrm{PM}_{2.5}$ aerosols in Eastern Central India: Influence of biomass burning and photochemical processing. Aerosol Air Qual. Res. 19: 2625-2644. https://doi.org/10.4209/aaqr.2019.10.0543

Douwes, J., Travier, N., Huang, K., Cheng, S., McKenzie, J., Le Gros, G., Von Mutius, E. and Pearce, N. (2007). Lifelong farm exposure may strongly reduce the risk of asthma in adults. Allergy 62: 1158-1165. https://doi.org/ 10.1111/j.1398-9995.2007.01490.x

Electricity Generating Authority of Thailand (EGAT) (2020). Mae Moh Power Plant, https:/www.egat.co.th/en/inform ation/power-plants-and-dams?view $=$ article \&id $=36$

Fang, C., Zhang, Z., Jin, M., Zou, P. and Wang, J. (2017). 
Pollution characteristics of $\mathrm{PM}_{2.5}$ aerosol during haze periods in Changchun, China. Aerosol Air Qual. Res. 17: 888-895. https://doi.org/10.4209/aaqr.2016.09.0407

Global Initiative for Asthma (GINA) (2008). Global strategy for asthma management and prevention (updated 2008). https://ginasthma.org/wp-content/uploads/2019/01/2008GINA.pdf

Hao, Y., Deng, S., Yang, Y., Song, W., Tong, H. and Qiu, Z. (2019). Chemical composition of particulate matter from traffic emissions in a road tunnel in Xi'an, China Aerosol Air Qual. Res. 19: 234-246. https://doi.org/10.42 09/aaqr.2018.04.0131

Health Effects Institute (HEI) (2010). Outdoor air pollution and health in the developing countries of Asia: A comprehensive review. https://www.healtheffects.org/pu blication/outdoor-air-pollution-and-health-developingcountries-asia-comprehensive-review

Hien, T.T., Chi, N.D.T., Nguyen, N.T., Vinh, L.X., Takenaka, N. and Huy, D.H. (2019). Current status of fine particulate matter $\left(\mathrm{PM}_{2.5}\right)$ in Vietnam's most populous city, Ho Chi Minh City. Aerosol Air Qual. Res. 19: 2239-2251. https://doi.org/10.4209/aaqr.2018.12.0471

Hoek, G., Dockery, D.W., Pope, A., Neas, L., Roemer, W. and Brunekreef, B. (1998). Association between $\mathrm{PM}_{10}$ and decrements in peak expiratory flow rates in children: Reanalysis of data from five panel studies. Eur. Respir. J. 11: 1307-1311. https://doi.org/10.1183/09031936.98. 11061307

Hong, Y.C., Pan, X.C., Kim, S.Y., Park, K., Park, E.J., Jin, X., Yi, S.M., Kim, Y.H., Park, C.H., Song, S. and Kim, H. (2010). Asian Dust Storm and pulmonary function of school children in Seoul. Sci. Total Environ. 408: 754759. https://doi.org/10.1016/j.scitotenv.2009.11.015

Hu, Q., Huang, C., Qiao, L., Ma, Y., Yang, Q., Tang, W., Zhou, M., Zhu, S., Lou, S., Tao, S., Chen, Y. and Li, L. (2019). Speciated PM composition and gas and particle emission factors for diesel construction machinery in China. Aerosol Air Qual. Res. 19: 1820-1833. https://doi.org/10.4209/aaqr.2018.07.0272

Huang, Y., Bao, M., Xiao, J., Qiu, Z. and Wu, K. (2019). Effects of $\mathrm{PM}_{2.5}$ on cardio-pulmonary function injury in open manganese mine workers. Int. J. Environ. Res. Public Health. 16: 2017. https://doi.org/10.3390/ijerph16112017

Jacquemin, B., Kauffmann, F., Pin, I., Le Moual, N., Bousquet, J., Gormand, F., Just, J., Nadif, R., Pison, C., Vervloet, D., Künzli, N. and Siroux, V. (2012). Air pollution and asthma control in the Epidemiological study on the Genetics and Environment of Asthma. J. Epidemiol. Community Health 66: 796-802. https://doi.org/10.1136 /jech.2010.130229

Jalaludin, B.B., Chey, T., O'Toole, B.I., Smith, W.T., Capon, A.G. and Leeder, S.R. (2000). Acute effects of low levels of ambient ozone on peak expiratory flow rate in a cohort of Australian children. Int. J. Epidemiol. 29: 549-557. https://doi.org/10.1093/ije/29.3.549

Kallawicha, K., Chuang, Y.C., Lung, S.C.C., Wu, C.F., Han, B.C., Ting, Y.F. and Chao, H.J. (2018). Outpatient visits for allergic diseases are associated with exposure to ambient fungal spores in the greater Taipei area. Aerosol
Air Qual. Res. 18: 2077-2085. https://doi.org/10.4209/aa qr.2018.01.0028

Kelly, F.J. and Fussell, J.C. (2011). Air pollution and airway disease. Clin. Exp. Allergy 41: 1059-1071. https://doi.org/ 10.1111/j.1365-2222.2011.03776.x

Kwon, H.J., Lee, S.G., Jee, Y.K., Lee, S.R. and Hwang, S.S. (2007). Effects of personal exposure to nitrogen dioxide on peak expiratory flow in asthmatic patients. J. Prev. Med. Public Health 40: 59-63. https://doi.org/10.3961/jp mph.2007.40.1.59

Lee, Y.L., Wang, W.H., Lu, C.W., Lin, Y.H. and Hwang, B.F. (2011). Effects of ambient air pollution on pulmonary function among schoolchildren. Int. J. Hyg. Environ. Health 214: 369-375. https://doi.org/10.1016/j.ijheh.201 1.05.004

Lewis, T.C., Robins, T.G., Dvonch, J.T., Keeler, G.J., Yip, F.Y., Mentz, G.B., Lin, X., Parker, E.A., Israel, B.A., Gonzalez, L. and Hill, Y. (2005). Air pollutionassociated changes in lung function among asthmatic children in Detroit. Environ. Health Perspect. 113: 10681075. https://doi.org/10.1289/ehp.7533

Li, T., Hu, R., Chen, Z., Li, Q., Huang, S., Zhu, Z. and Zhou, L.F. (2018). Fine particulate matter $\left(\mathrm{PM}_{2.5}\right)$ : The culprit for chronic lung diseases in China. Chronic Dis. Transl. Med. 4: 176-186. https://doi.org/10.1016/j.cdtm.2018.0 7.002

Li, W., Dorans, K.S., Wilker, E.H., Rice, M.B., Ljungman, P.L., Schwartz, J.D., Coull, B.A., Koutrakis, P., Gold, D.R., Keaney Jr, J.F., Vasan, R.S., Benjamin, E.J. and Mittleman, M.A. (2017). Short-term exposure to ambient air pollution and biomarkers of systemic inflammation: The Framingham Heart Study. Arterioscler. Thromb. Vasc. Biol. 37: 1793-1800. https://doi.org/10.1161/ATV BAHA.117.309799

Liu, L., Poon, R., Chen, L., Frescura, A.M., Montuschi, P., Ciabattoni, G., Wheeler, A. and Dales, R. (2009). Acute effects of air pollution on pulmonary function, airway inflammation, and oxidative stress in asthmatic children. Environ. Health Perspect. 117: 668-674. https://doi.org/ 10.1289/ehp11813

Liu, X., Jiang, N., Yu, X., Zhang, R., Li, S., Li, Q. and Kang, P. (2019). Chemical characteristics, sources apportionment, and risk assessment of $\mathrm{PM}_{2.5}$ in different functional areas of an emerging megacity in China. Aerosol Air Qual. Res. 19: 2222-2238. https://doi.org/10.4209/aaqr.2019.02.0076

Maciejczyk, P., Jin, L., Hwang, J.S., Guo, X., Zhong, M., Thurston, G. and Chen, L.C. (2018). Association of cardiovascular responses in mice with source-apportioned $\mathrm{PM}_{2.5}$ air pollution in Beijing. Aerosol Air Qual. Res. 18: 1839-1852. https://doi.org/10.4209/aaqr.2017.11.0504

Mann, J.K., Balmes, J.R., Bruckner, T.A., Mortimer, K.M., Margolis, H.G., Pratt, B., Hammond, S.K., Lurmann, F.W. and Tager, I.B. (2010). Short-term effects of air pollution on wheeze in asthmatic children in Fresno, California. Environ Health Perspect. 118: 1497-1502. https://doi.org/10.1289/ehp.0901292

Meng, Y.Y., Rull, R.P., Wilhelm, M., Lombardi, C., Balmes, J. and Ritz, B. (2010). Outdoor air pollution and uncontrolled asthma in the San Joaquin Valley, 
California. J. Epidemiol. Community Health 64: 142147. https://doi.org/10.1136/jech.2009.083576

Missagia, S., do Amaral, C.A.S., de Jesus, A.S., Arbex, M.A., Santos, U.P., de André, C.D.S., de André, P.A., do Nascimento Saldiva, P.H., Martins, L.C., Braga, A.L.F. and Pereira, L.A.A. (2018). Evaluation of peak expiratory flow in adolescents and its association with inhalable particulate in a Brazilian medium-sized city. Rev. Bras. Epidemiol. 21: e180009. https://doi.org/10.15 90/1980-549720180009

National Heart, Lung, and Blood Institute (NHLBI) (1997). Initial assessment and diagnosis of asthma. Pediatr. Asthma Allergy Immunol. 11: 15-24. https://doi.org/10.1 089/pai.1997.11.15

Obihara, C.C, Kimpen, J.L. and Beyers, N. (2007). The potential of Mycobacterium to protect against allergy and asthma. Curr. Allergy Asthma Rep. 7: 223-230. https://doi.org/10.1007/s11882-007-0076-1

Pan, W. (2001). Akaike's information criterion in generalized estimating equations. Biometrics 57: 120125. https://doi.org/10.1111/j.0006-341X.2001.00120.x

Park, J.W., Lim, Y.H., Kyung, S.Y., An, C.H., Lee, S.P., Jeong, S.H. and Ju, Y.S. (2005). Effects of ambient particulate matter on peak expiratory flow rates and respiratory symptoms of asthmatics during Asian dust periods in Korea. Respirology 10: 470-476. https://doi.org/ 10.1111/j.1440-1843.2005.00728.x

Pekkanen, J., Timonen, K.L., Ruuskanen, J., Reponen, A. and Mirme, A. (1997). Effects of ultrafine and fine particles in urban air on peak expiratory flow among children with asthmatic symptoms. Environ. Res. 74: 2433. https://doi.org/10.1006/enrs.1997.3750

Penttinen, P., Timonen, K. L., Tiittanen, P., Mirme, A., Ruuskanen, J. and Pekkanen, J. (2001). Ultrafine particles in urban air and respiratory health among adult asthmatics. Eur. Respir. J. 17: 428-435. https://doi.org/ 10.1183/09031936.01.17304280

Peters, A., Dockery, D.W., Heinrich, J. and Wichmann, H.E. (1997). Medication use modifies the health effects of particulate sulfate air pollution in children with asthma. Environ. Health Perspect. 105: 430-435. https://doi.org/ 10.1289/ehp.97105430

Pollution Control Department, Thailand (PCD) (2013). Thailand's pollution situation report 2012. http://infofile. pcd.go.th/mgt/DraftPolReport2555_25560214.pdf

Pride, N.B. (1992). Asthma. 3rd ed. In Physiology, Clark, T.H.J., Godlfrey, S. and Lee, H.T. (Eds.), Chapman and Hall Medical, London, pp. 14-72.

Qian, Z., Lin, H.M., Chinchilli, V.M., Lehman, E.B., Stewart, W.F., Shah, N., Duan, Y., Craig, T.J., Wilson, W.E., Liao, D., Lazarus, S.C. and Bascom, R. (2009). Associations between air pollution and peak expiratory flow among patients with persistent asthma. J. Toxicol. Environ. Health A 72: 39-46. https://doi.org/10.1080/15 287390802445517

Quanjer, P.H., Lebowiz, M.D., Gregg, I., Miller, M.R. and Pedersen, O.F. (1997). Peak expiratory flow: Conclusion and recommendations of a Working Party of the European Respiratory Society. Eur. Respir. J. 24: 2S-8S.
Rahman, S.A.A., Yatim, S.R.M., Abdullah, A.H., Zainuddin, N.A. and Samah, M.A.A. (2019). Exposure of particulate matter $2.5\left(\mathrm{PM}_{2.5)}\right.$ on lung function performance of construction workers. AIP Conf. Proc. 2124: 020030-1020030-7. https://doi.org/10.1063/1.5117090

Ray, D, Rajaratnam, A. and Richard, J. (1993). Peak expiratory flow in rural residents of Tamil Nadu, India. Thorax 48: 163-166. https://doi.org/10.1136/thx.48.2.163

Rohr, A.C. (2018). Ozone exposure and pulmonary effects in panel and human clinical studies: Considerations for design and interpretation. J. Air Waste Manage. Assoc. 68: 288-307. https://doi.org/10.1080/10962247.2018.14 24056

Samoli, E., Dimakopoulou, K., Evangelopoulos, D., Rodopoulou, S., Karakatsani, A., Veneti, L., Sionidou, M., Tsolakoglou, L., Grivas, G., Papakosta, D. and Katsouyanni, K. (2017). Is daily exposure to ozone associated with respiratory morbidity and lung function in a representative sample of schoolchildren? Results from a panel study in Greece. J. Exposure Sci. Environ. Epidemiol. 27: 346351. https://doi.org/10.1038/jes.2016.32

Schachter, E.N., Moshier, E., Habre R., Rohr, A., Godbold, J., Nath, A., Grunin, A., Coull, B., Koutrakis, P. and Kattan, M. (2016). Outdoor air pollution and health effects in urban children with moderate to severe asthma. Air Qual. Atmos. Health 9: 251-263. https://doi.org/10.10 07/s11869-015-0335-6

Seltzer, J., Bigby, B.G., Stulbarg, M., Holtzman, M.J., Nadel, J.A., Ueki, I.F., Leikauf, G.D., Goetzl, E.J. and Boushey, H.A. (1986). O3-induced change in bronchial reactivity to methacholine and airway inflammation in humans. J. Appl. Physiol. 60: 1321-1326. https://doi.org/ 10.1152/jappl.1986.60.4.1321

Shahid, I., Kistler, M., Shahid, M.Z. and Puxbaum, H. (2019). Aerosol chemical characterization and contribution of biomass burning to particulate matter at a residential site in Islamabad, Pakistan. Aerosol Air Qual. Res. 19: 148-162. https://doi.org/10.4209/aaqr.2017.12.0573

Silva, R.A., West, J.J., Zhang, Y., Anenberg, S.C., Lamarque, J.F., Shindell, D.T., Collins, W.J., Dalsoren, S., Faluvegi, G., Folberth, G., Horowitz, L.W., Nagashima, T., Naik, V., Rumbold, S., Skeie, R., Sudo, K., Takemura, T., Bergmann, D., Cameron-Smith, P., Cionni, I., Doherty, R.M., Eyring, V., Josse, B., MacKenzie, I.A., Plummer, D., Righi, M., Stevenson, D.S., Strode, S., Szopa, S. and Zeng, G. (2013). Global premature mortality due to anthropogenic outdoor air pollution and the contribution of past climate change. Environ. Res. Lett. 8: 034005. https://doi.org/10.1088/1748-9326/8/3/034005

Składanowski, M., Jarosz, P. and Mackiewicz, B. (2016). Variations of peak expiratory flow rate associated with various factors among healthy adults in a city setting. Pol. J. Public Health 126: 91-94. https://doi.org/10.1515/pjph2016-0019

Sordillo, J.E., Hoffman, E.B., Celedón, J.C., Litonjua, A.A., Milton, D.K. and Gold, D.R. (2010). Multiple microbial exposures in the home may protect against asthma or allergy in childhood. Clin. Exp. Allergy 40: 902-910. https://doi.org/10.1111/j.1365-2222.2010.03509.x 
Stanek, L.W., Brown, J.S., Stanek, J., Gift, J. and Costa, D.L. (2011). Air pollution toxicology-a brief review of the role of the science in shaping the current understanding of air pollution health risks. Toxicol. Sci. 120: S8-27. https://doi.org/10.1093/toxsci/kfq367

StatSoft, Inc. (2007). Time series analysis. Electronic Statistics Textbook Homepage. http://www.statsoft.com/ textbook/sttimser.html

Thepnuan, D., Chantara, S., Lee, C.T., Lin, N.H. and Tsai, Y.I. (2019). Molecular markers for biomass burning associated with the characterization of $\mathrm{PM}_{2.5}$ and component sources during dry season haze episodes in Upper South East Asia. Sci. Total Environ. 658: 708722. https://doi.org/10.1016/j.scitotenv.2018.12.201

Timonen, K.L. and Pekkanen, J. (1997). Air pollution and respiratory health among children with asthmatic or cough symptoms. Am. J. Respir. Crit. Care Med. 156: 546-552. https://doi.org/10.1164/ajrccm.156.2.9608044

U.S. EPA (2018). Particulate matter (PM) basics. United States of Environmental Protection Agency. https://www. epa.gov/pm-pollution/particulate-matter-pm-basics

Uno, H., Horiguchi, H., Omae, K., Uchiyama, I., Kudo, S. and Kayama, F. (2005). Effects of volcanic sulfur dioxide on reconstruction workers and residents returning to Miyake Island. Sangyo Eiseigaku Zasshi 47: 142-148. https://doi.org/10.1539/sangyoeisei.47.142

van der Zee, S.C., Hoek, G., Boezen, M.H., Schouten, J.P., van Wijnen, J.H. and Brunekreef, B. (2000). Acute effects of air pollution on respiratory health of 50-70 yr old adults. Eur. Respir. J. 15: 700-709. https://doi.org/10.1034 /j.1399-3003.2000.15d13.x

Wang, B., Zhou, Y., Xiao, L., Guo, Y., Ma, J., Zhou, M., Shi, T., Tan, A., Yuan, J. and Chen, W. (2018). Association of lung function with cardiovascular risk: A cohort study. Respir Res. 19: 214. https://doi.org/10.1034 /j.1399-3003.2000.15d13.x

Ward, D.J. and Ayres, J.G. (2004). Particulate air pollution and panel studies in children: A systematic review. Occup. Environ. Med. 61: e13. https://doi.org/10.1136/oe m.2003.007088

Weinmayr, G., Romeo, E., De Sario, M., Weiland, S.K. and Forastiere, F. (2009). Short-term effects of $\mathrm{PM}_{10}$ and $\mathrm{NO}_{2}$ on respiratory health among children with asthma or asthma-like symptoms: A systematic review and metaanalysis. Environ. Health Perspect. 118: 449-457. https://doi.org/10.1289/ehp.0900844

Weiss, S.T. and Ware, J.H. (1996). Overview of issues in the longitudinal analysis of respiratory data. Am. J.
Respir. Crit. Care Med. 154: S208-S211. https://doi.org/ 10.1164/ajrccm/154.6 pt 2.s208

Wichmann, H.E. and Heinrich, J. (1995). Health effects of high level exposure to traditional pollutants in East Germany: Review and ongoing research. Environ. Health Perspect. 103: 29-35. https://doi.org/10.1289/ehp.95103 s229

Widiana, D.R., You, S.J., Yang, H.H., Tsai, J.H. and Wang, Y.F. (2017). Source apportionment of air pollution and characteristics of volatile organic compounds in a municipal wastewater treatment plant, north Taiwan. Aerosol Air Qual. Res. 17: 2878-2890. https://doi.org/10.4209/aaqr.2 017.09.0317

Wiwatanadate, P. and Trakultivakorn, M. (2010). Air pollution-related peak expiratory flow rates among asthmatic children in Chiang Mai, Thailand. Inhalation Toxicol. 22: 301-308. https://doi.org/10.3109/08958370 903300327

Wiwatanadate, P. and Liwsrisakun, C. (2011). Acute effects of air pollution on peak expiratory flow rates and symptoms among asthmatic patients in Chiang Mai, Thailand. Int. J. Hyg. Environ. Health 214: 251-257. https://doi.org/10.1016/j.ijheh.2011.03.003

World Health Organization (WHO) (2014). Burden of disease from Ambient Air Pollution for 2012. https://www.who.int/airpollution/data/AAP_BoD_result s_March2014.pdf?ua=1

World Health Organization (WHO) (2020, May 20). Asthma. http://www.who.int/mediacentre/factsheets/fs307/en/

Xing, Y.F., Xu, Y.H., Shi, M.H. and Lian, Y.X. (2016). The impact of $\mathrm{PM}_{2.5}$ on the human respiratory system. $J$. Thorac. Dis. 8: E69-E74. https://doi.org/10.3978/j.issn. 2072-1439.2016.01.19

Yamazaki, S., Shima, M., Ando, M., Nitta, H., Watanabe, H. and Nishimuta, T. (2011). Effect of hourly concentration of particulate matter on peak expiratory flow in hospitalized children: A panel study. Environ. Health. 10: 15. https://doi.org/10.1186/1476-069x-10-15 Zhou, Y., Liu, Y., Song, Y., Xie, J., Cui, X., Zhang, B., Shi, T., Yuan, J. and Chen, W. (2016). Short-term effects of outdoor air pollution on lung function among female nonsmokers in China. Sci. Rep. 6: 34947. https://doi.org/10.1 038/srep34947

Received for review, March 6, 2020 Revised, April 27, 2020 Accepted, April 28, 2020 